\title{
GEOGRAFIA, LITERATURA E ARTE: \\ CAMINHOS DA GEOARTE
}

\author{
GEOGRAPHY, LITERATURE AND ART: \\ PATHS OF THE GEOART
}

\section{GEOGRAFÍA, LITERATURA Y ARTE: CAMINOS DE LA GEOARTE}

Júlio César Suzuki Universidade de São Paulo, São Paulo, Brasil

Gilvan Charles Cerqueira de Araújo Universidade de São Paulo, São Paulo, Brasil

Rita de Cássia Marques Lima de Castro Universidade de São Paulo, São Paulo, Brasil

A Revista de Geografia Literatura e Arte chega ao seu segundo número de 2020 com uma abertura reflexiva, prático-teórica e de possibilidades de pensamento, análise, metodologias e aproximações entre áreas do conhecimento. É nesse sentido que colocamos em evidência a ideia de Geoarte, no sentido mais amplo de expansão da geoliteratura e geopoética. A um só tempo, compreende-se a união possível e necessária entre o lastro científico representado inicialmente pela representação científicofilosófica da Geografia com as mais variadas formas de expressão do homo poeta nietzschiano para além das teorizações iniciais da geopoética outrora proposta por Michel Deguy e Kenneth White.

A Geoarte compromete-se com uma postura de totalização, um continuum que se retroalimenta pelas dimensões, fatos e fenômenos passíveis e possíveis de perpassarem os saberes e fazeres. Razão, emoção, ciência e metafísica, ora o caminho por entre o imagético, ora lançando mão do numérico, no encontro do filosóficoracional com (in)consciente do conhecimento produzido haverá a pulsão do criativo relacional no limiar do existente-existencial; é o que emana pelo texto e seus 'com- 
textos', presente nas entrelinhas de cada dado, lauda, registro, notas de pesquisa, ensaios etc.

A Geoarte presentifica-se, sulca meandros interdisciplinares, uni-diversificando filosofia, ciências, olhares, visões-de mundo, tradições, métodos, contradições e o criativo (i)nato da busca pelas inscrições do (des)conhecer-se que no perfaz. Por essa premissa e suas possiblidades e desafios apresentamos, a seguir, os artigos que compõem a presente edição da Geoliterart, em um longo e profícuo caminho.

O primeiro artigo dessa edição, Um lugar autônomo na cidade global: uma interpretação de "What we all long for" de Dionne Brand, é uma contribuição de Beatriz de Carvalho Monteiro, constituído com ideias, conceitos e problematizações da ensaísta, poetisa e romancista canadense, em reflexões correlacionadas das temáticas do contemporâneo global com questões de identidade, preconceito e imigração, principalmente por meio das experiências da personagem Oku, presente no romance de Dionne Brand.

Em Análise do Cordel no ensino de Geografia visão da periferia e a violência urbana, de autora de Julia Gabriela Lessa De Queiroz, Leandro Vieira Cardoso da Silva, Kelly Barradas Moreno, há um instigante trabalho de aproximação, diálogo e aplicação didático-pedagógica na educação básica, tendo como referência os aportes teóricos, conceitos e metodológicos da Geografia e Literatura.

Guido Lins Lopes Bragioni e Marina Araújo prospectam novas paragens ontológicas e epistemológica em seu artigo Corpo e espaço: uma reflexão dialética acerca do objeto de estudo da geografia. Espaço-corpo, metafísica da paisagem, a experiência do devir-vida e o entrecruzamento interdisciplinar necessário para alcançar imersões possíveis de observação, experiência e uma possível e quista alteridade da espacialidade complexa.

No estudo Cartografia poética dos escritores modernistas em belo horizonte$M G$ quando arte, literatura e vida se encontram, de Adriana Lacerda de Brito, Rosália Caldas Sanábio de Oliveira e Viviane Moreira Maciel, há uma demonstração de como elaborar um guia turístico literário. Em suas reflexões e análises geoliterárias lançam mão de ideias e conceitos como percepção, elementos epistemológicos da Geografia 
Cultural, interfaces e expressões imagéticas, geograficidade e as experiências dos estares no mundo por diferentes lugares pelas paisagens da capital mineira.

Em rica argumentação, teorização e análise, Suelen Rosa Pelissaro, em seu estudo Nonada ou a travessia: reflexões sobre o sertão de Guimarães Rosa e do Brasil, elabora correlações históricas, econômicas, geográficas, literárias e sociais da obra de Guimarães Rosa com elementos da formação territorial brasileira, elementos simbólicos e identitários dos interiores territoriais brasileiros e a importância dessas representações geoliterárias para a compreensão do ser social.

$\mathrm{O}$ artigo Turismo e literatura: análises a partir das lentes das mobilidades, de Carla Fraga, Maria Jaqueline Elicher e Camila Maria dos Santos Moraes, oferece um amplo estudo exploratório sobre os novos platôs de conceituação sobre os lugares, o turismo e os novos paradigmas de mobilidade do olhar, ser e experiência turística. $\mathrm{Na}$ caminhada analítica proposta no trabalho, verifica-se, por exemplo, a ampla e íntima relação entre turismo, literatura e geografia, que fazem parte de um movimento atual e instigante de repensar o turismo e as mobilidades em dimensões geoartísticas.

Geografia e Literatura unem-se, no enlace da Geoarte, em Vidas Secas de Graciliano Ramos: suas e outras paisagens pelas tintas naturais de solo, de autoria de Gabriela Sabatini Barros Sales, Jeferson Rosa da Silva, Maria Luiza Felix Marques Kede e Ana Claudia Ramos Sacramento, em experiência escrita, refletida e transcrita de oficinas pedagógicas interdisciplinares voltadas às representações da literaturapaisagem de Vidas Secas como metodologias de ensino e aprendizagem.

Em Cora Coralina: Uma poética sobre lugares e sabores, Marina Rossi Ferreira, e Marcos Alberto Torres realizam uma viagem pela Geografia dos Sabores dos versos coralinos. Imagem, memória, paisagens e lugares, o alimento e a experiência, todos perpassados pela escrita e sensibilidade da autora goiana são relacionados entre si pelos autores em seu artigo como rico exercício geopoético.

Com inspiração em autores como Cecília Meireles, Sophia de Mello B. Andresen e Clarice Lispector, Valéria Cristina Pereira da Silva elabora sua contribuição à Geoliterart, intitulada A Geografia serve, antes de tudo o mais, para fazer a viagem: real e imaginária. A partir dos relatos e percursos de viagem da Geografia Clássica aos 
modernos meios de se pensar o viajar pelas paisagens, encontramos nesse trabalho um convite singular, carregado de (re)significações das narrativas de viagem.

Em Cotidiano e factiricade: contribuições para uma geografia da escala mínima, Gilvan Charles Cerqueira de Araújo, inspirado pela Fenomenologia, defende a expressão literária como mediação na leitura da trivialidade fenomênica a partir de importante incursão filosófica em que categorias de análise complexas são operacionalizadas e dão densidade à argumentação, como as de epifania cotidiana, escrituração existencial e escala mínima; esta última em profundo diálogo com duas das mais essências da reflexão geográfica: escala e extensão.

Ainda nessa edição da revista de Geografia, Literatura e Arte, rememoramos os acontecimentos desse ano de 2020 iniciado com sussurros impactantes do porvir que se concretizara, meses depois, no decorrer da pandemia do vírus Sars-CoV-2. Entre confinamento e textualidades pandêmicas, Felipe Moura Fernandes apresenta, nas expressões geoliterárias, sua Poesia é espaço (corpo). Em uma expressão entre poesia e crônica, Maria Amélia Vilanova Neta brinda-nos com o texto Chove no Recife, em diálogo com Josué de Castro em Homens e Caranguejos.

Na seção das resenhas, temos a leitura de Carlos Cassiano Dalto sobre o clássico O Retrato de Dorian Gray de Oscar Wilde, publicado originalmente em 1890. O autor apresenta, com precisão, o intertexto presente na obra de Oscar Wilde, relatando o infrutífero labor da alta sociedade inglesa em tentar ludibriar aos outros, na busca de mostrar aspectos positivos de caráter que não correspondiam à realidade de suas ações.

Recebido em 05/11/2020.

Aceito em 05/11/2020.

Publicado em 07/11/2020. 